\title{
GENETIC VARIATION, HERITABILITY AND CORRELATION BETWEEN RESIN PRODUCTION CHARACTER OF Pinus merkusii HIGH RESIN YIELDER (Hry)
}

\author{
ARIDA SUSILOWATI ${ }^{*}$, ISKANDAR Z. SIREGAR ${ }^{2}$, SUPRIYANTO ${ }^{2}$, \\ IMAM WAHYUDI ${ }^{3}$ and CORRYANTI ${ }^{4}$ \\ 'Coordinatior of Private Higher Education Region I North Sumatera-Aceh, Indonesia \\ (Kopertis Wilayah I Sumut-NAD) \\ ${ }^{2}$ Silviculture Department, Faculty of Forestry, Bogor Agricultural University, Bogor, Indonesia \\ ${ }^{3}$ Forest Product Department, Faculty of Forestry Bogor Agricultural University, Bogor, Indonesia \\ ${ }^{4}$ Research and Development Center of Perum Perhutani, Bogor, Indonesia
}

Recipient of BIOTROP Research Grant 2010/Accepted 18 April 2013

\begin{abstract}
Tree improvement programs for high resin yielder P. merkusii were started in 2006 through a series of survey and morphological identification of candidate trees with high resin production. Specific information about genetic parameter of resin yielder candidates in Cijambu Seedling Seed Orchard is still not determined yet, although based on resin distribution trend this SSO has the highest mean of resin production. In this research, individual and family heritability, coefficient genetic variation and genetic-phenotypic correlation were estimated for resin production and growth data from 15 open polinated families of Pinus merkusii planted in 1982 (set 1) - 1983 (set 2) in Cijambu SSO. The results showed high value of coefficient genetic variation (CVG: 14.5-28.43\%), individual narrow sense heritability values for resin production character $(0.58-0.77)$ which resemble with previous researches. This indicates that genetic factor was dominant for resin production and selection activities were effective to get high yielder superior candidate. Phenotypic and genotypic correlation found that bark thickness, crown length and stem diameter character was positively significant correlated to resin production, whereas severity attack level of pests-diseases and number of branches were negatively significant correlated to resin production.
\end{abstract}

Key words: Selection, high resin yielder, P. merkusii, variation, heritability, phenotypic

\footnotetext{
*Corresponding author : arida_iswanto@yahoo.co.id
} 


\section{INTRODUCTION}

Pinus merkusii is known as an important industrial species for pulp and paper and sawn wood, gum rosin production, as well as considerable species for reforestation and land rehabilitation in Indonesia (Suhardi et al. 1994). One valuable product of resin and very demanded by international market is gondorukem (gum rosin). Gondorukem is a potential product, grouped under pine chemical products and it plays an important role as non timber forest product in Indonesia because it provides high national income about US\$ 50 million/year as well as more job opportunities (Fachrodji 2010).

Problems faced in gondorukem export was lower productivity so that Indonesia still ranks as third position after China and Brazil as gum rosin producer (Cunningham 2006). In order to sustain Indonesian gondorukem export, several activities have been undertaken to increase resin production through tree breeding activities, application of improved silvicultural techniques, improvement of tapping techniques and management (Fahrodji 2010). Breeding activities focusing on resin production is the most prospective way to be developed since early studies conducted in 2006, have resulted to several plus trees producing high yield of resin (high resin yielder). High resin yielder is the term given for pine genotype producing over $50 \mathrm{~g} /$ tree $/ 3$ days (Fakultas Kehutanan UGM 2006) higher than the current production $(21 \mathrm{~g} /$ tree $/ 3$ days).

P. merkusii breeding activities in Indonesia were started since 1976 through a series of progenies test and descendants of plus tree selection which was focused on stem straightness character (Soeseno 1988), while resin production is only a side product. In considering high value of resin products, pine breeding activities were recently conducted to obtain plus trees for resin production (Soeseno 2001). For breeding activities concentrating on resin yielder, it is important to collect information on genetic parameters such as coefficient of genetic variation, heritability and association of characters related to resin production for directing efficient selection. Several researches on P. merkusii conducted in early establishment of Seedling Seed Orchard (SSO) in Java and other pine species showed that resin production character has high heritability value, but specific information of Cijambu SSO is not determined yet. Therefore, research on "Genetic variation, heritability and correlation between resin production characters of Pinus merkusii High Resin Yielder (HRY) in Cijambu Seedling Seed Orchard (SSO)" is needed. The result will be used to provide best possible trees for further genetic improvement as well as to establish plantations using improved genetic materials.

\section{MATERIALS AND METHODS}

Experiment was carried out in Cijambu SSO, Sumedang. Data for this research were obtained from progenies test plantation established in 1982 (Set 1) and 1983 (set 2). At early plantation the research focused on stem character, where 200 families 
were planted/year designed in Completely Randomized Block Design, 5-tree line plot with ten blocks as replication at a spacing of $3 \times 3 \mathrm{~m}$. Together with selective thinning leaving only 2-3 trees per plot. Second selection focused on resin production conducted in 2006 found 96 families with 110 plus trees in progenies trial planted in 1978-1983. Planting year 1982 involved 20 open pollinated families and in 1983 involved 25 open pollinated families of resin yielder candidates spread in 2 different blocks. For CVG and heritability estimation, 15 selected open polinated families were used. In this research two assumption and 2 types of estimation were used, those were: 1) Resin production was not different at the age 29 and 30 years, for these reason we combined 2 set of families (1982 and 1983) into one estimation and 2). Resin production was different at the age of 29 and 30 years so we used separate estimation using set 1 and set 2 .

Characters studied in this research were resin production and other quantitative characters which assume to be related to resin production those were: total height $(\mathrm{TH})$, clear bole height $(\mathrm{CBH})$, diameter, crown length $(\mathrm{CL})$, crown width $(\mathrm{CW})$, number of branches (NB), first branch angle (FBA), bark thickness (BT), severity attack level from pest and disease (SL), clear bole volume (VBC) and total volume (Vtot). All characters were measured based on previous methods for forest trees developed by Bacilieri et al. (1996); Cantini et al. (1999); Kremer et al. (2002); Ginwal et al. (2004); Weber and Montes (2005); Baliuckas et al. (2005) and Devagiri et al. (2007). Resin production was measured by calculating resin tapping weight for 3 days.

\section{Data Analysis}

Analyses of variance (ANOVA) were carried out on Single Tree Plot design according to Isik (2008) using individual tree basis for each progeny test with following linear model:

$$
\mathrm{Y}_{\mathrm{i} \mathrm{k}:}: \mu+\mathrm{B}_{\mathrm{i}}+\mathrm{F}_{\mathrm{j}}+\mathrm{e}_{\mathrm{i} \mathrm{j} \mathrm{k}}
$$

where: $\mathrm{Y}_{\mathrm{ijk}}$ : individual tree observation; $\mu$ : the overall mean; $\mathrm{B}_{\mathrm{i}}$ : the effect of $i^{\text {th }}$ block; $F_{;}$: the effect of ${ }^{\text {th }}$ family; $\mathrm{e}_{\mathrm{ij \textrm {j }}}$ : within ploterror. Only 2 replications were included in the analyses. Variance and covariance component were calculated by equating the means square or mean cross product to their expectation. As progeny trial assumed to be half-sib, heritabilities and standar error (S.E) were estimated by using single site analyses formula:

heritability of family means:

$h^{2} \mathrm{f}: \sigma^{2} \mathrm{f} /\left(\sigma_{\mathrm{f}}^{2}+\sigma_{\mathrm{b}}^{2} / \mathrm{nb}+\sigma_{\mathrm{e}}^{2}\right)$, with S.E $h^{2} \mathrm{f}:\left(\mathrm{S} . \mathrm{E} \sigma^{2} \mathrm{f}\right) /\left(\sigma_{\mathrm{f}}^{2}+\sigma_{\mathrm{b}}^{2} / \mathrm{nb}+\sigma_{\mathrm{e}}^{2}\right)$,

individual tree heritability:

$h^{2}: 4 \delta^{2} \mathrm{f} /\left(\sigma_{\mathrm{f}}^{2}+\sigma_{{ }_{b+}}^{2} \sigma_{\mathrm{e}}^{2}\right)$, with S.E. $h^{2}:\left(4\right.$ S.E $\left.\sigma^{2} \mathrm{f}\right) /\left(\delta_{\mathrm{f}}^{2}+\sigma_{b_{+}}^{2} \sigma_{\mathrm{e}}^{2}\right)$

where: $h^{2} f$ : family mean heritability; $h^{2}$ :individual tree heritability; $\sigma{ }^{2} \mathrm{f}$ : the component due to family means; $\sigma_{\mathrm{b}}{ }_{\mathrm{b}}$ : the component of block; $\sigma_{\mathrm{e}}{ }_{\mathrm{e}}$ : the component of variance within plot. The standard error of family component variance (S.E $\left.\sigma^{2} f\right)$ was calculated by Anderson \& Bancroft (1952) in Hardiyanto (1996):

S.E $\sigma^{2} f:\left[2 / \mathrm{k}_{\mathrm{i}}^{2}\left(\mathrm{MS}_{\mathrm{i}}\right)^{2} /\left(\mathrm{df}_{\mathrm{i}}+2\right)\right]^{0.5}$ 
where: $\mathrm{k}$ is the coefficient of family means square; $\mathrm{MS}_{\mathrm{i}}$ the $\mathrm{i}^{\text {th }}$ means square used to estimate $\mathrm{n}^{\text {th }}$ component; df:the number of degree of freedom for $\mathrm{MS}_{\mathrm{i}}$ Criteria for heritability $\left(b^{2} f\right)$ was calculated according to Cotteril and Dean (1990).

Estimates of genetic variation coefficient performed using Cornelius (1994) formula as follows:

$$
\mathrm{CVG}=\frac{\sqrt{\sigma_{G x}^{2}}}{\bar{x}} \times 100 \%
$$

Genetic and phenotypic correlation between resin production character and growth character estimated using statistical formula as follows:

$$
\mathrm{r}_{\mathrm{P}(\mathrm{xy})}=\frac{\operatorname{Cov}_{P(x y)}}{\sqrt{\left(\sigma_{p x}^{2}\right)\left(\sigma_{p y}^{2}\right)}} \text { and } \mathrm{r}_{\mathrm{G} .(\mathrm{xy})}=\frac{\operatorname{Cov}_{G(x y)}}{\sqrt{\left(\sigma_{G x}^{2}\right)\left(\sigma_{G y}^{2}\right)}}
$$

\section{RESULTS AND DISCUSSION}

\section{Coefficient Genetic Variation (CVG)}

Estimates of variances and allied statistics for contributing sources of variability are presented for each trait in Table 1. Based on Cornelius (1994) classification, genetic variation in Cijambu SSO showed variation value with total character contribution ranging from $4.05 \%$ (total height character) to $28.70 \%$ (severity attack level from pest and disease). This result indicated that not all of the characters observed in Cijambu SSO were influenced by genetic factors. Resin production and severity attack level from pest-disease character have high value of coefficient genetic variations. Diameter, crown, bark thickness, number of branches, clear bole volume, total volume, have moderate value of coefficient genetic variations, while total height, clear bole height and branching angle in set 2 have lower value of coefficient genetic variations.

High CVG value represents resin production character (14.5-28.43\%) and severity attack level from pest-disease (24.0-28.70\%). It indicates that genetic factors will have a big impact on the appearance of characters. High value for resin production character was obtained compared to previous research conducted by Roberds et al. (2003) in P.taeda SSO (CVG:13.7\%). High value for severity attack level from pestdisease was also compared to Bastein \& Alia (2000) in P. sylvestris (CVG:26.8\%). In order to tree improvement focused on resin production in Cijambu SSO, these characters are important to be studied in detail because of the influence of genetic factors. CVG value for total height, clear bole height, crown width, crown length and number of branches character has lower value. It indicated that these characters belong to vegetative characters which is influenced by environmental factors. 


\section{Heritability}

Based on Cotteril and Dean (1990) classification, heritability value for resin production character at Cijambu SSO was high (h2f:0.700.09-0.820.08 and h2:0.580.08-0.770.08), severity attack level from pest-disease also has high heritability value (h2f: $0.640 .02-0.800 .16$ and h2:0.640.13-0.690.04). Stem diameter, bark thickness, crown length, number of branches and volume have lower to moderate heritability value (Table 1).

Table 1 . Family variance $\left(\sigma^{2} \mathrm{f}\right)$, block variance $\left(\sigma^{2} \mathrm{~b}\right)$, within plot error variance $\left(\sigma^{2} \mathrm{e}\right)$, coefficient of Genetic variation $(\mathrm{CVG})$, family heritability $\left(\mathrm{h}^{2} \mathrm{f}\right)$ and individual tree heritability for resin production and growth characters

\begin{tabular}{|c|c|c|c|c|c|c|c|c|}
\hline Characters & $\sigma^{2} \mathrm{f}$ & $\sigma^{2} \mathbf{b}$ & $\sigma^{2} \mathrm{e}$ & $\begin{array}{c}\text { CVG } \\
(\%)\end{array}$ & $h^{2} f$ & SE & $h^{2}$ & SE \\
\hline \multicolumn{9}{|l|}{29 and 30 years old } \\
\hline $\begin{array}{l}\text { Resin production days } \\
(\mathrm{g} / 3)\end{array}$ & 581.8 & 338.1 & 86.1 & 21.6 & 0.70 & 0.09 & 0.58 & 0.08 \\
\hline Total height (m) & 1.94 & 2.58 & 11.07 & 6.0 & 0.14 & 0.05 & 0.12 & 0.05 \\
\hline Clear bole height (m) & 3.40 & 7.0 & 3.39 & 6.6 & 0.33 & 0.23 & 0.25 & 0.17 \\
\hline Diameter (m) & 0.002 & 0.007 & 0.002 & 10.1 & 0.29 & 0.72 & 0.20 & 0.52 \\
\hline Bark thickness $(\mathrm{cm})$ & 0.36 & 0.89 & 0.26 & 8.8 & 0.34 & $0 . .83$ & 0.24 & 0.58 \\
\hline Number of branches & 55.92 & 69.15 & 33.17 & 12.8 & 0.45 & 0.10 & 0.35 & 0.08 \\
\hline Crown length (m) & 1.507 & 3.122 & 1.74 & 10.6 & 0.31 & 0.30 & 0.24 & 0.23 \\
\hline Crown width (m) & 1.272 & 2.96 & 1.55 & 12.5 & 0.30 & 0.30 & 0.22 & 0.21 \\
\hline First branch angle & 105.97 & 34.32 & 58.12 & 11.2 & 0.58 & 0.10 & 0.53 & 0.09 \\
\hline Clear bole volume $\left(\mathrm{m}^{3}\right)$ & 0.002 & 0.009 & 0.04 & 13.9 & 0.35 & 0.22 & 0.33 & 0.20 \\
\hline Total volume $\left(\mathrm{m}^{3}\right)$ & 0.007 & 0.34 & 0.14 & 9.4 & 0.18 & 0.60 & 0.12 & 0.42 \\
\hline $\begin{array}{l}\text { Severity attack level } \\
\text { from pest and disease }\end{array}$ & 139.91 & 15.75 & 49.86 & 28.2 & 0.71 & 0.13 & 0.68 & 0.12 \\
\hline \multicolumn{9}{|l|}{ Set 1 (29 years old) } \\
\hline $\begin{array}{l}\text { Resin production days } \\
(\mathrm{g} / 3)\end{array}$ & 200.70 & 53.94 & 46.82 & 14.5 & 0.72 & 0.13 & 0.67 & 0.19 \\
\hline Total height (m) & 0.67 & 3.5 & 21.83 & 3.3 & 0.04 & 0.01 & 0.03 & 0.03 \\
\hline Clear bole height (m) & 1.69 & 3.5 & 6.08 & 4.89 & 0.21 & 0.11 & 0.15 & 0.13 \\
\hline Diameter (m) & 0.001 & 0.0005 & 0.002 & 7.9 & 0.47 & 0.15 & 0.36 & 0.04 \\
\hline Bark thickness (cm) & 0.27 & 0.36 & 0.12 & 6.5 & 0.39 & 0.15 & 0.36 & 0.54 \\
\hline Number of branches & 15.73 & 77.16 & 40.13 & 13.2 & 0.14 & 0.03 & 0.12 & 0.09 \\
\hline Crown length (m) & 2.42 & 3.02 & 1.13 & 13.0 & 0.40 & 0.48 & 0.37 & 0.18 \\
\hline Crown width (m) & 1.11 & 1.56 & 3.26 & 10.3 & 0.26 & 0.18 & 0.19 & 0.05 \\
\hline First branch angle & 6.4 & 36.15 & 106.2 & 2.8 & 0.07 & 0.01 & 0.04 & 0.02 \\
\hline Clear bole volume $\left(\mathrm{m}^{3}\right)$ & 0.02 & 0.002 & 0.07 & 13.1 & 0.31 & 0.16 & 0.19 & 0.06 \\
\hline Total volume $\left(\mathrm{m}^{3}\right)$ & 0.06 & 0.07 & 0.23 & 13.8 & 0.25 & 0.15 & 0.17 & 0.37 \\
\hline $\begin{array}{l}\text { Severity attack level } \\
\text { from pest and disease }\end{array}$ & 95.59 & 5.29 & 37.83 & 24.0 & 0.80 & 0.16 & 0.69 & 0.04 \\
\hline
\end{tabular}


Table 1. Continued

\begin{tabular}{|c|c|c|c|c|c|c|c|c|}
\hline Characters & $\sigma^{2} \mathrm{f}$ & $\sigma^{2} \mathbf{b}$ & $\sigma^{2} \mathrm{e}$ & $\begin{array}{l}\text { CVG } \\
(\%)\end{array}$ & $h^{2} f$ & SE & $h^{2}$ & SE \\
\hline \multicolumn{9}{|l|}{ Set 2 (30 years old) } \\
\hline $\begin{array}{l}\text { Resin production }(\mathrm{g} / 3 \\
\text { days) }\end{array}$ & 1012.5 & $\begin{array}{l}151.2 \\
5\end{array}$ & 151.3 & 28.43 & 0.82 & 0.084 & 0.77 & 0.08 \\
\hline Total height (m) & 1.15 & 1.02 & 0.86 & 4.64 & 0.46 & 0.06 & 0.38 & 0.52 \\
\hline Clear bole height $(\mathrm{m})$ & 3.08 & 6.75 & 0.33 & 4.91 & 0.45 & 0.09 & 0.30 & 0.06 \\
\hline Diameter $(\mathrm{m})$ & 0.002 & 0.01 & 0.001 & 8.49 & 0.19 & 0.07 & 0.12 & 0.411 \\
\hline Bark thickness (cm) & 0.09 & 0.19 & 0.38 & 10.93 & 0.16 & 0.01 & 0.14 & 0.29 \\
\hline Number of branches & 66.50 & 14.09 & 5.61 & 8.12 & 0.84 & 0.05 & 0.70 & 0.41 \\
\hline Crown length (m) & 0.82 & 0.05 & 1.007 & 7.81 & 0.44 & 0.06 & 0.44 & 0.55 \\
\hline Crown width (m) & 0.50 & 0 & 0.48 & 7.84 & 0.51 & 0.09 & 0.51 & 0.01 \\
\hline First branch angle & 201.95 & 18.75 & 75 & 5.26 & 0.71 & 0.10 & 0.68 & 0.10 \\
\hline Clear bole volume $\left(\mathrm{m}^{3}\right)$ & 0.04 & 0.03 & 0.009 & 12.04 & 0.62 & 0.09 & 0.50 & 0.06 \\
\hline Total volume $\left(\mathrm{m}^{3}\right)$ & 0.14 & 0.33 & 0.009 & 13.06 & 0.38 & 0.08 & 0.26 & 0.07 \\
\hline
\end{tabular}

Heritability for resin production shows high value (0.580.08-0.770.08). It seems to be slightly different than previous research results (0.69) conducted by Leksono (1990) at Cijambu and Sempolan on 12 years old P. merkusii progenies test plantation. This result was higher than reported by Zhang et al. (2010) on P. eliotii (0.37), Tadesse et al. (2001) on P. pinaster (0.5) and Roberds et al. (2003) on P. taeda (0.44 to 0.59), and similar value was also found at stem diameter and branching quality. Higher value in this research compared to previous researches at early SSO establishment suggested that the materials used for this research originated from second selection focused for resin production. For high resin production heritability values, Wenger (1984); Burczyk et al. (1998); Kassuth et al. (1984); Mergen et al. 1955, Gill (1998) explained that resin production character is controlled by gene. This indicates that improvement program for resin production character through genetic selection would provide higher genetic gain not affected by other interaction factors.

Heritability value for height and stem diameter were slightly different from previous researches conducted by Hardiyanto (1996) who focused on stem straightness, and Leksono (1996) for resin yield at 12 years old progenies test (h2f: 0.40 dan h2f: 0.43). Heritability value for branching trait character is lowe in set $1(0.12$ and 0.07 ) but in set 2 the heritability value is high (0.44 dan 0.71$)$. The changes of heritability value in long rotation crops such as a tree is not surprising since genes involved in growth may change with age (Namkoong et al. 1980; Monteuis et al. 2011), and these changes also may be related to different growth phases (Franklin 1979). Change of heritability value for diameter, tree height and bark thickness character at different age probably is influenced by silvicultural practices such as thinning and other management practices (Gwaze et al. 1997 \& Lopez-Upton et al. 1999).

Result from CVG and heritability estimation in Cijambu SSO showed high value for resin production, it indicated that more dominant genetic factors determine this character. Based on this value, tree improvement program for high resin yielder can be initially conducted by mass selection of individual trees with high resin production. 
This condition agrees with Tadesse et al. (2001) who stated that when a population has high heritability value for a character, mass selection method would be more efficient for improving the character. Furthermore, White et al. (2007) stated that mass selection was appropriate to be implemented in early selection and for high heritability value characters because the phenotypes of individual trees describe its genetic ability.

\section{Phenotypic and Genetic Correlation Between Growth Character and Resin Production}

Phenotypic and genotypic correlation (Table 2) showed low to moderate coefficient value, indicated that not overall phenotypic appearance describing genetic expression because interaction between environment and genetic factor also influencing phenotypic expression of trees. Phenotypic correlation showed resin production character was positively significant correlated with stem diameter, bark thickness and crown length. Furthermore, number of branches and severity attack level from pest -disease character was negatively significant correlated with resin production. Positive correlation between resin productions with some characters, indicated that resin production will increase equally with the increase of character value. On the other hand, a negative correlation between resin production with some characters indicates that resin production will decrease with high value of character components.

Genetic correlation between resin production and stem diameter, bark thickness, and crown length indicated that resin production will increasedequally with the increase of these characters. On the contrary resin production will decrease equally with the increase of branching number and severity attack level of pest-disease. Different results were obtained in set 2 ( 30 years old progenies trial), in set 2 we found negative correlation between resin production and tree height, it indicates that resin production will decrase with the increase of tree height.

Correlation between resin production with stem diameter and crown length are in accordance with previous research results conducted by Pswaray et al. (1996); Coppen et al. (1984) on P.elliottii; Westbork (2011) on P.taeda and Tadesse et al. (2001) on P.pinaster. Panshin \& De Zeeuw (1984) also explained that a good naval store tree is characterized by large diameter and large crown size because trees need more wider light absorbance for photosynthesis process. Correlation between resin production and stem diameter have been reported also by Coppen et al.1984 who stated that wider diameter trees have wider annual ring and giving great chance to have more resin ducts and produce higher resin yield than smaller diameter trees.

Number of branches and severity attack level from pest and disease have negatively significant effect to resin production meaning that resin production decreased with the increasing number of branches and severity attack level from pest. Papajiannopoulos (2002) in P.halepensis also found that tree with canopy openes (lower branch number) have higher resin yield compared with higher branch number which assume to be related to photosyntetic process, resin viscocity and accumulation. Correlation between resin production and severity attack level from pest-disease have been deeply studied in other pine species and conifers. Previous researches conducted 
Genetic variation, heritability and correlation between resin production character - Arida Susilowati et al.

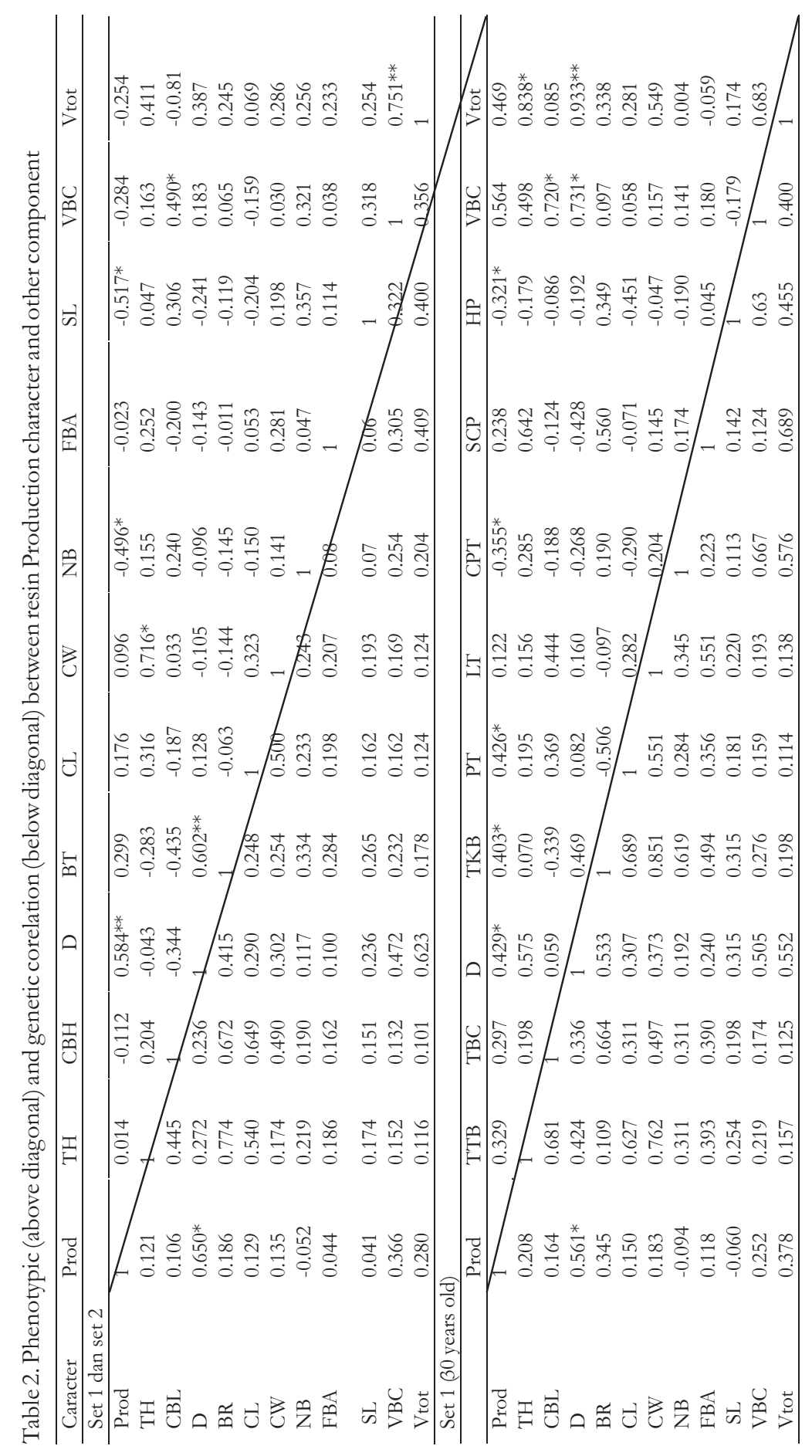




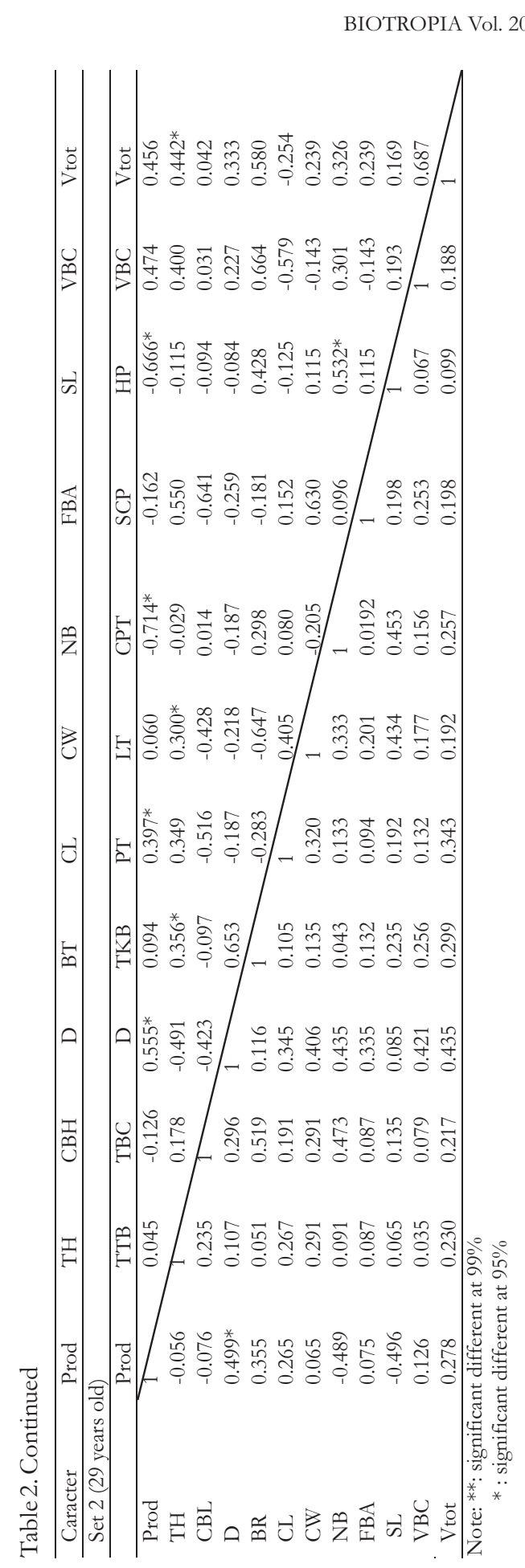


in temperate regions by Kleinhentz et al. (1998); Blada (2000); Kim et al. (2003); Rafael et al. (2005) concluded that pest and disease caused significant decrease of resin production quantities. Furthermore, Raffa \& Berryman (1982) in P.taeda also found severity attack level which caused loss of resin yield quantities. However, specific studies about correlation between resin production and severity attack level in Cijambu SSO have not been conducted yet. From this research we found that both resin production and severity attack level in Cijambu SSO have high CVG value, it indicated that selection activities focused for resin production also can escorted together with resistance for pest and disease.

Although some characters have a correlation to resin production, further research still need to be conducted because phenotypic observation is influenced by growth phase and environment, so it could not differentiate recessive genotype with resemble morphological appearance such as secondary metabolites (Finkeldey 2005). To overcome this problem molecular marker such as RFLP, RAPD, AFLP and microsatellite can be used.

\section{CONCLUSIONS}

Results from genetic variation and heritability estimation of resin yielder candidates character in Cijambu SSO showed high coefficient of genetic variation value (CVG: $14.5-28.43 \%$ ) and heritability value (h2:0.580.08-0.770.08) for resin production character. It indicated that genetic factor strongly affected resin production character.

Genetic and phenotypic correlation found that stem diameter, bark thickness and crown length character were positively significant correlated to the resin production, whereas severity attack level from pest-disease and number of branches was negatively significant correlated to resin production. It indicated $t$ genetically improvement on stem diameter, bark thickness and crown length increasing resin production. Whereas, higher severity attack level from pest-disease and number of branches decreased resin production.

\section{ACKNOWLEDGMENTS}

This research was part of Arida Susilowati's studies toward doctorate degree from Bogor Agricultural University (IPB). I would like to express my sincerest thank to SEAMEO-BIOTROP for supporting my research with $P h D$ research grant. My sincerest appreciation also goes to Research and Development Center of the Perum Perhutani for the access to their experimental plot in Cijambu SSO and in providing samples as well as for technical assistance during the fieldwork. 


\section{REFERENCES}

Baliuckas VT, Lagerstrom I, Norell and G Eriksson 2005. Genetic variation among and within populations in swedish species of Sorbus aucuparia L. and Prunuspadus L. assessed in a nursery trial. Silvae Genetica, 54: 1-8.

Bastein C, Alia R. 2000. What Might be useful Measures of Genetic Variability for Adaptive Characters within Populations of Scots Pine?. Invest. Agr.: Sist. Recur. For Fuera de Serie n. ${ }^{\circ} 1: 2$.

Burczykj, Lewandowskai, Chojnackib 1998. Resin production of scots pine trees may be associated with multilocus allozyme variation. Arboretum Kdrnickie, 43:79-83.

Bacilieri R, Ducousso A, Kremer A. 1995. Genetic, morphological, ecological and phenological differentiation between Quercus petraea (Matt.) Liebl. and Quercus robur L in a mixed stand of Northwest France. Silvae Genetica, 44(suppl 1): 1-10.

Blada I. 2000. Genetic variation in blister rust resistance and growth traits in Pinus strobus hybrid at age 17. Forest Genetics, 7(suppl2):109-120.

Cantini C, Climato \& Sani G. 1999. Morphological evaluation of olive germplasm present in Tuscany region. Euphytica, 109:173-181.

Coppen JJW, Greenhalgh P, Smith AE. 1984. Gum Naval Stores: Turpentine an Industrial Profile of Production and Rosin from Pine Resin. Tropical Development and Research Institute. Report No. G187: 40 Pp.

Cornelius J. 1994. Heritabilities and genetic coefficients of variation in forest trees. Canandian Journal of Forestry Research, 24:372-379.

Cotteril PP, Dean CA. 1990. Succesfull Tree Breeding with Index Selection. CSIRO Division of Forestry dan Forest Product. Australi.

Cunningham A. 2006. A Revies of The Past Years Pine Chemical in Brazil. Presentation to 2006 China Gondorukem Trade Conference. Guangzho.

Devagiri GM, Dhiman RC, Naveen KP, Patil CSR. 2007. Short Note: Seed source variation in seedling and nodulation characters in Dalbergia Sissoo Roxb. Silvae Genet, 56: 88-91.

Fachrodji A. 2010. Model daya saing produk gondorukem di pasar internasional dan implikasinya terhadap pengembangan industri gondorukem di Indonesia. PhD thesis. Institut Pertanian Bogor.

Fakultas Kehutanan UGM. 2006. Laporan Penelitian Pinus Bocor Getah No.04/SJ/PBC/2006. Kerjasamaa Pusat Penelitian dan Pengembangan Perum Perhutani Cepu dan Fakultas Kehutanan Universitas Gadjah Mada. Yogyakarta.

Finkeldey R. 2005. Introduction Tropical Forest Genetics. E. Jamhuri, IZ Siregar, UJ Siregar and AW Kertadikara, translator. Gottingen: Institute of Forest Genetics and Forest Tree Breeding, Georg-August-Göttingen Univerity. Translation of: An Introduction to Tropical Forest Genetics.

Franklin EC. 1979. Model Relating Level of Development of Four North American Conifer. Silvae Genetica, 28:207-212.

Gill JGS. 1988. Juvenile-mature correlations and trends in genetic variances in sitka spruce in Britain. Silvae Genet, $36: 189-194$

Ginwal US, Rawat PS, Srivastava RL. 2004. Seed source variation in growth performance and oil yield of Jatropha curcas L. in central India. Silvae Genet, 53: 186-192.

Gwaze DP, Woolliams JA, Kanowski PJ. 1997. Genetic parameters for height and stem straightness in Pinus taeda Linnaeus in Zimbabwe. For. Genet1997, 4:159-169.

Hardiyanto EB. 1996. Genetic parameter estimates for stem form and diameter in two Pinus merkusii Jungh et de Vries progeny test in Java,Indonesia. In: Dieter MJ, Matheson AC, Nikles DG, Harwood CE, Walker SM, editor. Tree Improvement for Sustainable Tropical Forestry. QFRI-IUFRO Conference; Queensland: 27 October1 November 1996

Ishik F. 2013. Analysis of half-sib progeny tests in forestry. 2008.Http:www4.ncsu [3 Maret 2013]

Kim MS, Brunsfeld SJ, McDonald GI, Klopfenstein NB. 2003. Effect of white pine blister rust (Cronartium ribicola) and rust-resistance breeding on genetic variation in western white pine (Pinus monticola). Theor ApplGenet, 106:1004-1010. 
Kleinhentz M, Raffin A, Jactel H. 1998. Genetic variabels and gain expected from direct selection for resistance to Dioryctria sylvestrella ratz. (Lepidoptera:Pyralidae) in Pinus pinaster ait using a full diallel mating design. Forest Genetics, 5:3:147-154.

Kossuths V. 1984. Multipurpose Slash Pine - Genetics and Physiology of Gum Naval Stores Production. USDA Fol: Sew. General Tech. Report, Northeastern Sta, Ne-90:77-83.

Kremer A et al. 2002. Leaf morphological differentiation between Quercus robur and Quercus petraea in stable across western european mixed oak stands. Annals of Forest Sciences, 59: 777-787.

Leksono B. 1996. Heritabilitas dan perolehan genetik produksi getah, diameter batang, bentuk batang dan percabangan Pinus merkusii JUNGH et De Vries. Buletin Penelitian Kebutanan, 11(suppl 2): 223-236.

Lopez-Upton J, White TL, Huber DA. 1999. Effects of site and intensive culture on family differences in early growth and rust incidence of loblolly and slash pine. Silvae Genet, 48: 284-293.

Mergen F, Hoekstra P, Echols RM. 1955. Genetic control of oleoresin yield and viscosity in slash pine. Forest Science, 1(suppl 1):19-30.

Monteuis O, Goh DKS, Garcia C, Alloysius D, Gidiman J, Bacilieri R, Chaix G. 2011. Genetic variation of growth and tree quality trait among 42 diverse genetic origins of Tectona grandis planted under humid tropical condition in Sabah, East Malaysia. Tree Gen Genome, 7:1263-1275.

Namkoong, Barnes RD, Burley J. 1980. Screening in yield in forest tree breeding. Commonw. for Rev, 59(suppl 1).

Panshin AJ, De Zeeuw C. 1984. Textbook of Wood Technology. Vol. I - Structure, Identification, Uses, and Properties of Commercial Woods of the United States and Canada, 3rd ed., The American Forestry Series, Vaux H.J. (Ed.), McGraw-Hill Book Company, 705 p.

Papajiannopoulos A. 2002. Leaflet of resin tapping. - PRISMA Ltd. Athens, in Greek.

Pswaray IZ, Barnes RD, Birks JS, Kanowski PJ. 1996. Genetic Parameter Estimates for Production and Quality Characters of Pinus elliottii ENGELM. var. elliottii in Zimbabwe. Silvae Genetica, 45.

Rafael Z, Luis S, Eva P, Josefa FL. 2005. Genetic variation of Pinus pinaster Ait. seedlings in susceptibility to the pine weevil Hylobius abietis L. Ann. For. Sci2005, 62:681-688.

Raffa KF, Berryman KA. 1982. Physiological differences between lodgepole pine resistance and susceptible to the mountain beetle and associated microorganisms. Environ. Entomol:11:486-492.

Roberds JH, Strom BL, Brain FP, Gwaze DP, Mc Keand DP, Lot LH. 2003. Estimates of genetic parameters for oleoresin and growth characters in juvenile loblolly pine. Can. J. For. Res, 33: 2469-2476.

Soeseno OH. 1988. Genetic variation and improvement of Pinus merkusii Jungh. Et De Vriese. PhDThesis, Gadjah Mada University, Indonesia.

Soeseno OH. 2001. Current status of tree improvement in Indonesia. In in situ and ex situ Conservation of Commercial Tropical Timber. Yogyakarta:11-13 June.

Suhardi, Sosef MSM, Laming PB, Ilic J. 1994. Pinus L. In Plant Resources of South-East Asia 5(1) Timber trees: Major commercial. Jansen PCM, Westphal E, Kartasubrata J. (eds.), 349-357 pp. PROSEA Bogor Indonesia. $610 \mathrm{pp}$.

Tadesse W, Nanos N, Aunon FJ, Alia R, Gill L. 2001. Evaluation high resin yielder of Pinus pinaster Ait. Forest Genetic, 8 (Suppl 4): 271-278.

Weber JC, Sotelo Montes C. 2005. Variation and Correlations Among Stem Growth and Wood Characters of Calycophyllum Spruceanum Benth. From The Peruvian Amazon. Silvae Genet, 54:31-40.

Westbrook J. 2011. Quantitative Genetics of Constitutive Oleoresin Defense in Loblolly Pine. Southern Forest Tree Improvement Conference.

White TL, Adam W'T, Neale DB. 2007. Forest Genetic. Cromwell Press Group. Trowbridge.

Zhang JH, Shen F, Jiang J , Luan Q, Yang Q, Xu Y, Liu Z. 2010. Heritability estimates for real resin capacity and growth characters in high-gum-yielding slash pine. CNKI. 03-010. 